\title{
Rеввавси автісів: Effect of drip fertigation on growth and yield of castor + onion intercropping system
}

\author{
K.R. PUSHPANATHAN, B.J. PANDIAN, G. MARIAPPAN AND P. JEYAKUMAR
}

Article Chronicle : Received : 14.07.2017;

Accepted : 29.07.2017

\section{KEY Words :}

Rabi castor, Drip irrigation, Fertilizer levels, Growth character, Yield attributes, CEY
SUMMARY : Field experiments were carried out in the farmer's field at Kokalai village, Namakkal during Rabi 2011-12 and 2012 - 13 to study the effect of drip irrigation regimes and fertigation levels on growth yield attributes of castor and onion crops, castor equivalent yield in castor with onion intercropping system. Results revealed that drip irrigation at 80 per cent CPE recorded significantly better growth characters of castor like plant height, leaf area index (LAI), yield attributes viz., length of primary spike; number of capsule per primary spikes; total number of spikes per plant; 100 seed weight and castor equivalent yield than 60 per cent and 40 per cent CPE during both the years. Among the different fertilizer levels, application of 100 per cent RDF as water soluble fertilizer (WSF) registered better growth characters $v i z$., plant height, LAI, yield attributes and castor equivalent yield during both the years compared to other treatments. The onion growth characters viz., plant height, number of leaf sheaths, single bulb yield and number of bulb per plant ${ }^{-1}$ were significantly influenced by drip irrigation at 80 per cent and 100 per cent RDF as water soluble fertilizer during both $2011-12$ and $2012-13$.

How to cite this article : Pushpanathan, K.R., Pandian, B.J., Mariappan, G. and Jeyakumar, P. (2017). Effect of drip fertigation on growth and yield of castor + onion intercropping system. Agric. Update, 12 (TECHSEAR-4): 1099-1104; DOI: 10.15740/HAS/AU/12.TECHSEAR (4)2017/1099-1104.

\section{Author for correspondence :}

K.R. PUSHPANATHAN Tamil Nadu Veterinary and Animal Sciences University, CHENNAI (T.N.) INDIA

Email: pushpanathanr4 @ gmail.com

See end of the article for authors' affiliations 